\section{Two RFLPs at the TNP1 locus}

\section{C.F.Hoth and W.Engel ${ }^{1}$}

Center for Human Genetics, Boston University School of Medicine, 80 E. Concord Street, Boston, MA 02118, USA and ${ }^{1}$ Institut fur Humangenetik der Universitat, Goßlerstraße 12d, D-3400 Gottingen, FRG

Source/Description: The Human Transition Protein 1 gene (TNP1) probe (1) used was a 700 bp genomic DNA sequence cloned into the SmaI site of pUC8 and was supplied by W.Engel.

Polymorphisms: TNP1 identifies a two allele polymorphism with TaqI: $\mathrm{A} 1=9.6 \mathrm{~kb} ; \mathrm{A} 2=8.4 \mathrm{~kb}$.

Frequency: Analysis of 20 unrelated individuals yielded frequencies: $\mathrm{A} 1=0.23 ; \mathrm{A} 2=0.77$.

Not Polymorphic For: BanI, BclI, BglI, BstEII, EcoRI, HaeIII, HindIII, MspI, NcoI, PstI, PvuII, RsaI in a screen of 10-20 unrelated individuals.

Mendelian Inheritance: Autosomal co-dominant segregation has been demonstrated in 3 families.

Probe Availability: Contact Hannelore Kremling, Institut fur Humangenetik der Universitat, Gossler Strasse 12D, 3400 Gottingen, FRG.

Source/Description: Oligonucleotide primers from sequence information of the TNP1 gene were used to amplify a $1.7 \mathrm{~kb}$ region encompassing the gene.

PCR Primers:

5' CCA TTG ATG TTG ACA GTA GCA 3' (TN1)

5' CAC CTA GCT CAG GAA CTC AA 3' (TN2)

Polymorphisms: MspI idnetifies a two-allele polymorphism with bands of 1059 bp (B1), $355+704$ bp (B2) and a constant band of $633 \mathrm{bp}$. PflMI identifies a similar polymorphism.

Frequencies: Analysis of 30 unrelated individuals yielded frequencies of: $\mathrm{B} 1=0.45 ; \mathrm{B} 2=0.55$. and heterozygote frequency $=0.60$ for both MspI and PflMI.

Not Polymorphic For: BsaAI, BstNI, HhaI, StuI, TaqI in 10-20 unrelated individuals.

Chromosomal Localization: TNP1 has been localized to 2q35-q36 by somatic cell hybridization and in situ hybridization (1).

Mendelian Inheritance: Autosomal co-dominant segregation has been demonstrated in 9 families.

Other Comments: The MspI polymorphism is in linkage disequilibrium with the PflMI polymorphism.

PCR Conditions: $0.5-1 \mu \mathrm{g}$ of genomic DNA was amplified with 5 pmoles of each primer, 1 unit Taq polymerase (Cetus), 200 $\mu \mathrm{M}$ dNTPs, in Cetus reaction buffer. PCR amplification was for 30 cycles at $94^{\circ} \mathrm{C}$ for $1.4 \mathrm{~min}, 58^{\circ} \mathrm{C}$ for 2 minutes

Acknowledgements: This work was supported by an NINCDS contract to the International Waardenburg Syndrome Consortium.

Reference: 1) Luerssen et al. (1990) Genomics 8, 324-330.
Dinucleotide repeat polymorphism in the human coagulation factor XI gene, intron $B(F 11)$, detected using the polymerase chain reaction

\author{
P.Bodfish, D.Warne, C.Watkins, K.Nyberg and \\ N.K.Spurr \\ Imperial Cancer Research Fund, Clare Hall Laboratories, \\ South Mimms, Potters Bar, Herts EN6 3LD, UK
}

Source/Description: The polymorphic sequence $(\mathrm{CA})_{11}$ starts at base 212 of intron B of the human coagulation factor XI gene (1). The sequence was identified from a search of the EMBL and GenBank DNA sequence databases (GenBank M21185; M18297). The predicted amplified sequence length is $360 \mathrm{bp}$.

\section{Primer Sequences: \\ 5'TCACCCAAGTAGTGAACACAGC3' \\ 5'GGTTGTTTCCACCTGTAATCC3'}

$\begin{array}{lll}\text { Frequency: } & & \\ \text { Allele } & \text { Size (bp) } & \text { Frequency } \\ \text { D1 } & 376 & 0.47 \\ \text { D2 } & 372 & 0.53\end{array}$

Heterozygosity $45 \%$ (estimated using 40 unrelated Caucasian individuals)

Mendelian Inheritance: Observed in CEPH families 1029 (Utah pedigree K1345) and 982 (Utah pedigree K1331).

Other Comments: 30 cycles of PCR were performed (2) using 200-300 ng of genomic DNA and $150 \mathrm{ng}$ of each primer in a final reaction volume of $50 \mu \mathrm{l}$. The reaction mix contained a final magnesium concentration of $1.5 \mathrm{mM}, 10 \%$ dimethyl sulphoxide (DMSO) and $0.1 \mathrm{mM}$ trimethylammonium chloride (TMAC). Primers were designed using the program PRIMER (3).

Chromosomal Localization: 4q35.

References: 1) Asakai,R., Davie,E.W. and Chung,D.W. (1987) Biochemistry 26, 7221 -7228. 2) Weber,J.L. and May,P.E. (1989) Am. J. Hum. Genet. 44, 388-396. 3) Lowe,T., Sharefkin,J., Yang,S.Q. and Dieffenbach,C.W. (1990) Nucl. Acids Res. 18, 1757-1761. 